\title{
PTX3 Gene
}

National Cancer Institute

\section{Source}

National Cancer Institute. PTX3 Gene. NCI Thesaurus. Code C119680.

This gene is involved in complement recognition of pathogens. 